University of Louisville

ThinkIR: The University of Louisville's Institutional Repository

Electronic Theses and Dissertations

$12-2018$

\title{
North American indigenous collection and curation and its impact on market arts.
}

Adelaide McComb

University of Louisville

Follow this and additional works at: https://ir.library.louisville.edu/etd

Part of the American Art and Architecture Commons, Art and Materials Conservation Commons, Contemporary Art Commons, Indigenous Studies Commons, Other History of Art, Architecture, and Archaeology Commons, Painting Commons, and the Printmaking Commons

\section{Recommended Citation}

McComb, Adelaide, "North American indigenous collection and curation and its impact on market arts." (2018). Electronic Theses and Dissertations. Paper 3091.

https://doi.org/10.18297/etd/3091

This Master's Thesis is brought to you for free and open access by ThinkIR: The University of Louisville's Institutional Repository. It has been accepted for inclusion in Electronic Theses and Dissertations by an authorized administrator of ThinkIR: The University of Louisville's Institutional Repository. This title appears here courtesy of the author, who has retained all other copyrights. For more information, please contact thinkir@louisville.edu. 


\title{
NORTH AMERICAN INDIGENOUS COLLECTION AND CURATION AND ITS IMPACT ON MARKET ARTS
}

\author{
By \\ Adelaide McComb \\ B.A., Colorado State University, 2011
}

\author{
A Thesis \\ Submitted to the Faculty of the \\ College of Arts and Sciences of the University of Louisville \\ In Partial Fulfillment of the Requirements \\ For the Degree of \\ Master of Arts \\ In Art (C) and Art History, Critical and Curatorial Studies \\ Department of Fine Arts \\ University of Louisville \\ Louisville, Kentucky
}

December 2018 
Copyright 2018 by Adelaide McComb

All rights reserved 



\title{
NORTH AMERICAN INDIGENOUS COLLECTION AND CURATION AND ITS
} IMPACT ON MARKET ARTS

\author{
By \\ Adelaide McComb \\ B.A., Colorado State University, 2011
}

Thesis Approved on

November $29^{\text {th }}, 2018$

by the following Thesis Committee:

\begin{tabular}{c}
\hline Chris Reitz \\
\hline Janet Kelly \\
\hline Rachel Singel
\end{tabular}




\section{ABSTRACT \\ NORTH AMERICAN INDIGENOUS COLLECTION AND CURATION AND ITS IMPACT ON MARKET ARTS}

Adelaide K. McComb

November 29, 2018

This thesis examines the history of two North American Indigenous groups, those belonging to the Great Plains and the Arctic, and observes how settler-colonial influence determined the collection and curation of arts and artifacts in these areas. This art includes a mention of pre-Colombian works, but focuses predominantly on works being made after "first-contact" through the contemporary ear. The paper addresses the effect imperialist history has had on the development of Indigenous art markets, and how institutions such as museums may address them through ethical practices, and efforts to decolonize museum spaces. 


\section{TABLE OF CONTENTS}

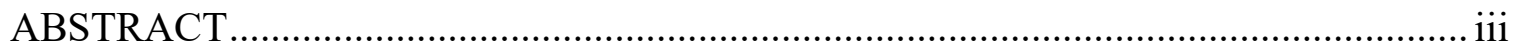

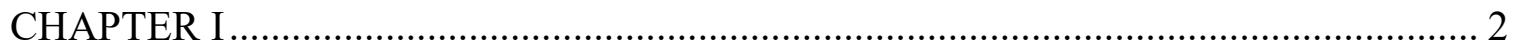

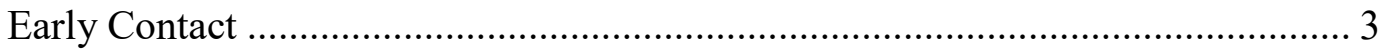

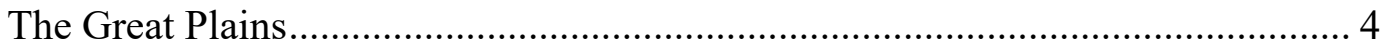

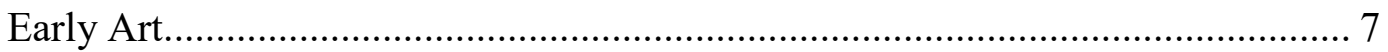

The Emergence of Plains Culture and Art .......................................................... 9

George Catlin and Carl Bodmer ........................................................................ 13

The Civil War and Westward Expansion.......................................................... 16

The Great Depression and The Santa Fe School ................................................ 20

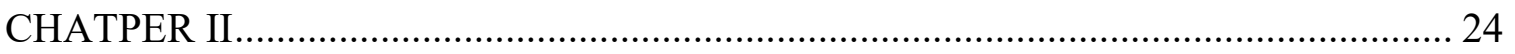

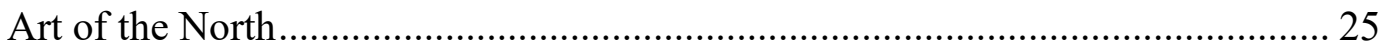

James Hudson and Dorset Fine Arts ................................................................. 28

Cape Dorset Print Collective ................................................................................ 29

Modern and Post-Contemporary Inuit Art ............................................................ 31

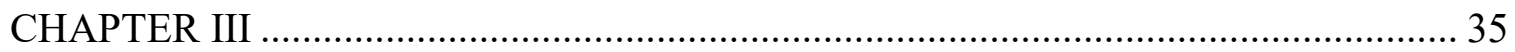

Collecting the Vanishing West ……………………….................................... 38

The Indigenous Art Market.................................................................................. 43

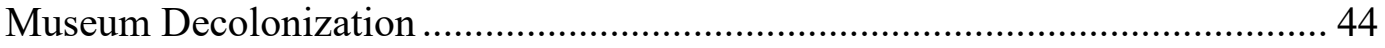

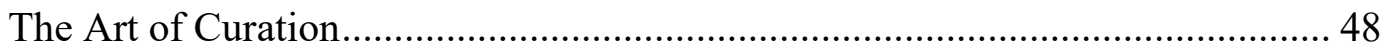

d'Harnoncourt and the Affinity for the Primitive and the Modern....................... 49 
Primitivism: The Tribal and the Modern

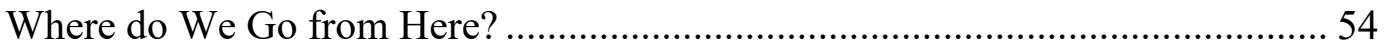

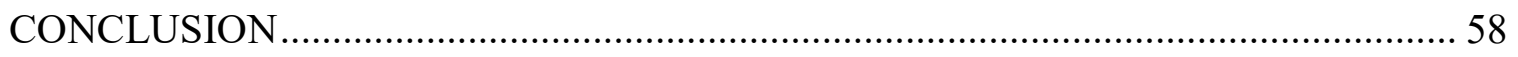

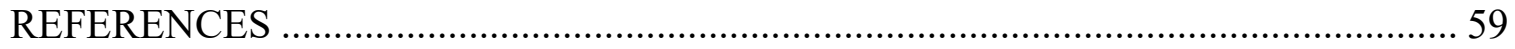

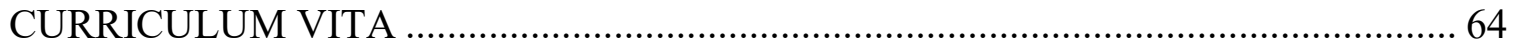




\section{INTRODUCTION}

For nearly 500 years the history of colonial powers vying for rights in the "new world" has implicitly or explicitly affected the art of the continent's original inhabitants. European attitudes towards and reception of Indigenous art has largely been and artefact of colonial dominance in history and art. In observing the influence settler-colonialism has had on the collection, curation, and creation of Indigenous art, this paper will examine two North American Indigenous cultures and how their various art markets were developed within this system. The people of the Great Plains and of the Alaskan and Canadian Arctic have had incredibly different histories in regards to the establishment of a fine art market despite having relatively similar experiences in colonialism.

In understanding the historic context of creation, collection, and curation of these cultures non-Native curators can begin to understand how they may partake in measures to sustain more equitable practices in the management of marginalized works, and assist in efforts to decolonize museums and historic institutions. The history of Indigenous art in North America is complex, and while it is often viewed as an alternative perspective in national history, the history of Native fine art is so intertwined with colonial efforts that it is impossible to discuss modern and contemporary Indigenous fine arts without exploring the effect colonialism has had on it. 


\section{CHAPTER I}

\section{AN ARTISTIC HISTORY OF THE GREAT PLAINS}

Despite the fact that there are more than 500 Indigenous tribal languages in the United States, years of stereotypical imagery has solidified the Plains Indian as the personification of the race in the minds of most people (Dockstader, 1974, Greene, 2014). One recalls the buckskin, beadwork, and long fringed shirts, made popular through an ever-recurring motif in marketing and popular media. The image of the brave warrior and daring horseman did not start with the circulation of the spaghetti western. Seeds were sown from the very first interactions between Indigenous Americans and European colonizers (Ewers, 1957, Doggett, 1992). The Western perception of the people of the Great Plains was a result of imperialist practices adopted in the establishment of the United States, and the creation and development of Indigenous work was frequently a reaction to such perceptions.

The earliest example of this pattern was established immediately after the arrival of Columbus, and continued for the next 500 years. In the early stages of colonization, Indigenous populations and cultures shifted with the arrival of settlers. The most immediate effect was felt among communities in the East. As colonial populations grew, many tribes in the woodlands found themselves in a westward diaspora as a result of government policy, urbanization and its impact on natural resources, and unfriendly populations. Populations living on the Great Plains changed, customs merged, and a new 
culture was developed. Many of the artifacts and art coming from this region are a result of this movement.

\section{$\underline{\text { Early Contact }}$}

On his first return from the Central Americas, Columbus brought with him a sampling of Indigenous folk, gathering volunteers (and more often captives) from several islands. During his second voyage, Columbus brought roughly 600 Indigenous people back to Europe, all captives (Doggett, 1992). About a third of the captives died at sea, half were ill upon arrival, and nearly all succumbed to disease upon arriving in Europe. No sooner had the discovery of a new race taken place, then exploitation began (Meyer \& Royer, 2001). Justified as a study in ethnography, Native Americans in captivity were forced into pageantry and parades. When no captives could be obtained, Indians were "created" in minstrel fashion. These events took place on a grand scale, as at the 1550's pageant for France's Henri II at Rouen, where hundreds of "pseudo-Indians" and a handful of Indigenous Americans inhabited a mock village (Doggett, 1992). It wasn’t just minstrel and pageantry, images circulating through Europe's largely illiterate masses depicted Natives as savage and uncivil, and many depicted ruthless acts of cannibalism, suggesting not only were the people of the so-called new world degenerate, they lacked basic humanity (Doggett, 1992). The depiction of the Indian as savage cemented an understanding of Indigenous cultures in the mind of Europeans long before they set foot upon the continent, and would affect the reception of any art or craft coming from such communities.

All manner of eating was depicted with derogatory overtones; the potato, not yet a staple of European diet, was observed as an inferior substitute to bread. Hunting for wild 
game was compared to the base instincts of ravenous animals. Such propagation of the inhabitants of the new world was used widely to justify the wide scale abduction of Indigenous people and promote colonization as a benevolent act.

The British propaganda campaign for colonization was led by the Protestant split from the Catholic church. Creating a narrative that positioned the Spanish as cruel, greedy, and blood thirsty, Britain could generate a sympathetic agenda for christening the Natives, and through Jesus bring them to civility. In looking to emphasize the humanity and docility of the race, England promoted anecdotal examples of successful assimilation. Lady Rebecca, or Pocahontas as she is more commonly referred to, was a prime example of successful peaceful and welcome colonization efforts. Far less publicity was granted to the Roanoke tribes who expressed hostility to the colonizers (Driskill, Finley, Gilley, \& Morgensen, 2011).

This form of British colonization starting as early as the $16^{\text {th }}$ century was the ground work for horrible acts of genocide, assimilation, forced relocation, immeasurable poverty, and took a tremendous toll on the arts. Patriarchal and colonial policies have affected how historians, archeologists, anthropologists, collectors, museums and galleries valuate the art and craft of Native Americans, much of which were rooted in the British colonial agenda. The effects of these policies have had lasting impacts on the collection and curation of these works. Many tribes have differing experiences with colonization, depending on their geographic location, culture, or access to trade (among other things). Some of the earliest impacted, and among those who faced some of the most dire lasting consequences, were the Indigenous of the Great Plains.

\section{The Great Plains}


As far as art goes, relatively little is known about the work in this area prior to settler colonialism, partly due to the fact that many works were produced on organic materials, such as hides, clay, wicker, wood, bone or stone and have not weathered well with time. Another factor is the massive amounts of culture and history intentionally destroyed in puritan fires, or lost to war, genocide, or relocation. While some artifacts remain, such as medicine wheels, mound houses, and petroglyphs, they have relatively little influence on the art coming out of this area (or in the case of permanent medicine wheels and mound houses, were predominantly part of sacred cultural practices), and thus will not be covered in this paper.

The Great Plains is a term that covers a wide region, and a multitude of tribes. Additionally, throughout the past 300 years, the boundaries have been in constant flux. Generally, the geographical boundaries span from the Eastern Woodlands to the east (just east of the Mississippi river), to the Rocky Mountains to the West, and from Southern Texas and encapsulating Southern Canada to the North (Berlo \& Phillips, 1998). Accounting for the peoples who lived in this area is challenging: Early settlers often misunderstood, or destabilized, existing social structure in order to advance their colonial aspirations. Early peoples were often ascribed inaccurate names.

While the term "Indian" is still in common use, I will avoid its application in this paper favoring instead more appropriate terms. "Native," "Indigenous" as well "Aboriginal" and "First Nations" in Canada, are preferred terms as they speak to the primary occupation of North America. In speaking of specific ethno-linguistic groups, the terms "Tribe," "Nation," and "Band" may be used. Band has widely been adopted in Canada, while the term Tribe has been employed in the United States within all federal 
treatise and documentation. The term Nation was intentionally avoided by governing officials in the US in an effort to remove a sense of self-governance among tribes. Nation has largely been adopted in both Canada and the US in recent years (Newcomb, 2004).

The populations who have historically occupied the great plains have fluctuated due to nomadic patterns, the introduction of the horse, settler colonialism, governmental land treaties, and military occupation. The Northern portion of the Great Plains has, and continues to be occupied by, Assiniboine, Plains-Cree, Ojibwe, Blackfeet, Gros Ventre, and small but resilient Arikara, Mandan and Hidatsa tribes. South of the present-day Canadian border, in the areas defined today as North and South Dakota, Montana, Wyoming, Wisconsin, and Nebraska, the Lakota, Cheyenne, and Crow defined their homelands. Farther south Arapaho, Omaha, Pawnee, Kiowa, and Comanche (Berlo \& MacDonald 1992, Maurer, 1992). North and South Dakota are occupied by the Lakota, Dakota and Nakota people (Greene, 2014). Referred to by some academics and scholars as the Sioux Nation, the term "Sioux" originates from the Ojibwe term for "little snakes," and was adopted and immortalized by Lewis and Clark (Dockstader, 1974). The term is widely considered pejorative, and for this paper, the term Lakota will be adopted in its place. Of these three subdivisions, there are several bands. The Oglala, Sicangu, Hunkpapa, Miniconjou, Sihasapa, Oohanunpa and Itazipacola fall under the Lakota Nation. The Mdewakanton, Wahpekute, Wahpeton, and Sisserton belong to the Dakota division, while the Yankton and Yanktonai belong to the Nakota. Geographically speaking, the Lakota are located to the West, with the Dakota to the East and Nakota occupying the middle territory. 
Ethnographically the Lakota, Dakota and Nakota all come from the same ethnolinguistic origins. The Plains tribes grew from earlier, similar ethnic configurations (Berlo \& Phillips, 1998), while bands like the Shoshone and Comanche influence within Plains culture was the result of the Westward relocation of the Lakota after the arrival of Eastern settlers.

\section{Early Art}

The earliest art found in this area includes petroglyphs, burial mounds, and stone medicine wheels. Dating back as far as $5000 \mathrm{BCE}$, these artistic remnants exist more as an artifact of tradition than artistic expression (Brody, 1971). Petroglyphs located throughout the Plains are believed to have spiritual and medicinal purposes, though these purposes can only be inferred through oral traditions (Maurer, 1992). Often referred to as 'rock art' the medium has been practiced by several of the plains tribes including the Gros Ventre, Cheyenne Shoshone, Blackfeet, Cree and Assiniboine. The style was practiced as early as $2500 \mathrm{BCE}$ and continued through the nineteenth century as evidenced by the inclusion of horses and firearms (Maurer, 1992).

Early rock art has many of the same stylistic elements that appear in later forms of Indigenous craft. Particular elements unique to Plains style include bilateral symmetry, geometric abstractions, and anthropomorphized figures (Brody, 1971). Of the rock art found within the Great Plains, compositions can be categorized by four types: abstract shapes and marks, animal tracks as well as human and foot prints, animals, and representations of humans. (Maurer, 1992). 
It is unknown who created the more ancient petroglyphs such as those found in the Cheyenne and Gros Ventre territories of present day Wyoming. The Cheyenne claim not to have created the images, nor do they know who did. Gros Ventre oral traditions indicates a difference between those made by the Plains people, and those made by tciya :tsine :n, or ghost men (McCleary, 2016). These petroglyphs were a series of semiotic icons, that were apt to change, and liable to disappear. To both the Crow and the Gros Ventre, the meaning of the ahpaláaxaawaalaache (ghost writing) had predictive powers, particularly ominous forewarnings of tragic deaths, or the fate of the warrior reading them. (Maurer, 1992, McCleary, 2016).

Cheyenne, Crow, and Gros Ventre-made petroglyphs had similar composition. Many are speculated to be the result of vision quests, the spiritual practice of medicine, protection, or ritual (Maurer, 1992). Many of these compositions contain anthropomorphized animals, frequently bilateral in symmetry, having rectilinear bodies, and highly abstracted arms and legs. Others depict shields. These are composed of geometric patterns, and representations of animals. The protective purpose of the shield, as well as the design and composition are found in painted and quilled shields presently.

In the protohistoric period, occurring in the early seventeenth century through the late eighteenth century, rock art began to take on additional stylistic properties. WritingOn-Stone, one of the largest petroglyph sites in the northern Plains, contains several examples of both "prehistoric" work (fourteenth through eighteenth centuries) and protohistoric work. This site, located in the Milk River valley, has historically been home to the Shoshone, Blackfeet, Cree, Assiniboine, and Gros Ventre. Of the nearly seven hundred images in the valley, $95 \%$ of them are made by a method of scratching and 
incising a style that was employed during the mid-eighteenth century to the midnineteenth century. These images tend to be more biographical in nature, and include representations of both horses and firearms, items which were common in plains life by 1750 (Maurer, 1992).

All of the images are similar in both style and composition, and are similar in style to Cheyenne and Crow drawings as well, from the composition of humans, the depiction of animals, and tracks. The difference appears to be greater between time periods than amongst tribes. Later depictions included new elements, not just technologies like the firearm, but depictions of time and action, elements which appear regularly in Plains painted hides (Maurer, 1992).

\section{The Emergence of Plains Culture and Art}

Though a Plains culture had existed prior to the seventeenth century, the introduction of the horse and westward expansion of settlers created a new and distinct culture. Though the tribes such as the Lakota and the Crow had been nomadic, the introduction of the horse increased their range of such tribes. Groups that had previously been settled, such as the Comanche, are encompassed within Plains culture (Brody, 1971). Due in part to their nomadic nature, contact in between Plains tribes increases. Common spiritual practices, such as the sun dance, are found in virtually all Plains tribes. Many of these religious ceremonies had a component of artistic rendering; costumery played a large part in in many cultural aspects of Plains life.

In fact, most Plains art was worn (Brody, 1971). Hide paintings, either those of buffalo, elk, or deer, were worn by prominent figures, quilled shields adorned warriors, 
cradles for babies, and coveted beaded-sole moccasins for those who spent more time on horseback than on the ground. Nearly all artistic work coming out of nomadic tribes was portable in nature. This included items like tipi covers and linings, which often bore winter counts or depictions of historical events, parfleche, quivers, among others. Among these items, two distinct styles emerge: geometric abstractions and biographical representations.

The earliest western documentation of these works was provided by explorers in the eighteenth century. In 1738, Veredyre documents both Mandan and Assiniboine arts, the Mandan, he notes, are "skillfully crafted" artists. Anthony Henry made note of Blackfoot painting in 1755, noting the fine lines and richness of color, and Alexander Mackenzie made passing reference to the painted buffalo robes and beaver hides he encountered in the Upper Missouri River region (Ewers, 1957). However, it wasn't until Lewis and Clark began documenting their exploration of the region in 1804 that hides began entering into the western documentation of the Plain canon.

The robes that Lewis and Clark noted were of Teton Lakota origin, known for the incorporation of "lavish" color (Ewers, 1957). The painted robes, at times adorned with quill work, and as trade increased, beadwork. While different tribes used different color pallets, many of the Plains artists used similar pigments. Earth tones were principally used, particularly red, yellow and brown. Red was achieved by treating a tallow ochre with heat. Closer to the Rockies, earth green was incorporated.

As nearly every aspect of life included high amounts of decoration, both men and women participated in the creation of art. Men's paintings followed the tradition of the later style of biographical rock art; Life forms, visions, winter counts, or chronologies of 
significant events often decorated the robes of prominent male figures, and were often highly personal or celebratory (Brody, 1971, Ewers, 1957). Winter counts were pictorial histories and could span decades or even centuries (Berlo \& Phillips, 1998). The artist was the author of the chronology and as such, could take liberty in depicting significant biographical events.

Stylistically, these works were flat, semi-abstract and often omitted detail. Details of the work were gleaned from context and the legacy of the wearer. Due to the display of the hides, the canvases had no top or bottom; hides were painted on the ground and worn as an outer garment (Ewers, 1971). Chronological paintings may have followed a spiral pattern indication the passage of time, or may be depicted in clustered events that suggested a specific indexing of events.

Other hides were decorated with highly abstracted designs. These works were completed by women, and often incorporated elements of other media such as quill work, and later beadwork. John Ewers observed several samples of Plains hides, and categorized the geometric designs into several categories. Several examples of abstract hides paining included a border. The border is continuous and follows the shape of the tanned hide, at times extending into the head. Within the border, other abstractions are detailed; several examples contain an hour glass shape made up of smaller, individual shapes and a mosaic of color. Many examples contained a box on one side of the animal's natural spine. Others contained shapes or icons in bilateral symmetry. This could include abstractions of feathers (two different colored isosceles triangles with their bases touching to create a bicolored diamond), pipes, shields, compasses, interlocking waves, and other curvilinear shapes (Ewers, 1957) 
The shape of the hide, and natural features of the animal were often central in the composition. Dedication to the decoration of the hides paid honor to the life of the animal, and the process of painting a hide (often communal) was as much a part of the work as the outcome itself. Many practices of Indigenous art include this hybridization of performance and visual art. Tipi covers and lining were painted by a selected guild, with the finished object being in some ways less important than the undertaking. This practice is not all together uncommon, many tribes include detailed decoration of funerary objects such as masks, kachina dolls, and in the healing purposes of sand painting. In this regard, these objects are neither performance art, nor visual arts; reproduction of these items in photographs.

In this regard, Indigenous art in general, and Plains art specifically, has been at the mercy of the Western critic. The figures found on eighteenth and nineteenth century hide paintings continue to be described to this day as "primitive," "childlike," "flat," and lacking in perspective and composition. Other critics argue that "vexing" problems of art, such as foreshortening, realism, and color modeling were avoided by artists, implying that these were not stylistic devices, but indications of inferior civilizations. At a time when realism was highly valued by both the Western artist and critic, these stylized and abstract works proved an impossible narrative of history.

The function of Indigenous painting was not "merely to establish a realistic record." The world exists as a realistic representation of the world, and a painting was a combination of the legacy, biographies, and visions of the wearer. The distinction between history and vision was not significant. Without understanding the cultural competence of Indigenous America, these works cannot be critiqued in fairness; the 
consequence of this has affected the social development and economic participation in the art market for nearly 200 years.

\section{George Catlin and Carl Bodmer}

In the summer of 1832, the United States government sent artist George Catlin to the great plains to document the state of civilization in the West. Catlin arrived in the upper Missouri river region and began his documentation of the Mandan, Hidatsa and Arikara (Ewers, 1957). Catlin was a prolific artist, and created roughly 20 portraits of the Eastern Plains people, and 20 landscape paintings. For many Anglo-Americans, this was the first time they had seen any imagery of Indigenous people. These works were lauded as the most accurate depiction of Native life in the Great Plains ever to be created, yet they carried inherent bias, and as a result had implications for the appreciation and reception of Native craftwork.

This was not the first time the Mandan, Hidatsa or Arikara had encountered the white man: traders, trappers, explorers and government officials had made their way west, however no artists "skilled in the realistic nineteenth century style" of art had interacted with the tribes prior (Ewers, 1957). Not only did Catlin create portraits of the people, he also captured the robes of several plains tribes, including Blackfoot, Cree, Mandan, Arikara, Lakota, Crow, Assiniboine, Cheyenne, Pawnee, Omaha, Comanche Apache, Ojibwe, and several others. Catlin's style of work was gestural and lacked high attention to detail, particularly in regards to wardrobe and costumery.

One of the Chief crucial to the success of Catlin's mission was Chief Four Bears. Four Bears, who himself was an artist, presented Catlin with a painted robe upon his 
departure. The robe has been lost, but not before Catlin was able to make a reproduction. The reproduction, however, does not appear to be true to life. Catlin, who documented the artistic motifs and designs of multiple tribes, appears to represent the stylized horses of all tribes in the same manner: "hooked hooves, a straight belly and a large phallus." (Ewers, 1957). While these are the characteristics of a few tribes, there was hardly stylistic uniformity through out the Plains. These inconsistencies discredit some of the work in Catlin portfolio. His portraits, however, may be among the truest representations of Plains chiefs at this time.

The following year, German Prince Maximilian zu Wied brought Carl Bodmer, a Swiss draftsman to the United States. Prince Maximilian was conducting large scale, inthe-field research of the Indigenous West, and hired Bodmer to recreate faithful images of his observations. Like Catlin, many of Bodmer's images capture the cultural and ceremonial life of the Mandan, Bodmer and Maximillian even developed a strong relationship with the same Chief Four Bears who had been instrumental in Catlin's success. However, Bodmer was a meticulous draftsman; his renderings of painted hides are much more faithful to life than those of Catlin.

It is no doubt that the artistic practices influenced the Eastern Plains tribes to some extent; both Catlin and Bodmer remarked at how their in-the-field practices were attentively observed by Indigenous onlookers. It is also clear that on an individual basis, the artistic styles of European nineteenth century realism may have affected the work of hide-painting artists. Chief Four Bears, for example, incorporated color-modeling into hides illustrations after his interactions with the artists. It was Bodmer's intent, in particular, to "improve" the quality of work coming from the Plains, which Maximilian 
noted "were no better than those drawn by children." (Ewers, 1957). Bodmer furnished the many of the Mandan with paper and watercolors, encouraging them to create pictures for himself and the Prince.

However, what these books tend to overlook are the consequences that arose when both Catlin and Bodmer brought back their "faithful" representations of Plains life. Catlin brought back the first visual rendering of the Okipa, the Mandan sacrificial ceremony similar to the Sun Dance (Berlo \& Phillips, 1998, Ewers, 1957). The practice of self-sacrifice as associated with the Sun Dance is a form of prayer that comes from Indigenous beliefs of ownership. In order for a prayer to have significance, the individual must sacrifice something that has deep meaning and significance to them. Many nomadic tribes believe the only worldly object anyone has ownership of is their own flesh. The Okipa, the K'ado, the Massaum, and various other forms of the Sun Dance all involve sacrifice of the flesh in order to strengthen the medicinal power of prayer (Berlo \& Phillips, 1998, Johnson 1994). The image Catlin brought back did not reflect the nuance of personal prayer and self-sacrifice; it depicted "submission to excruciating torture" (Ewers, 1957). The Sun Dance was banned by the United States Government in 1883 (Berlo \& Phillips, 1998).

Bodmer and Maximilian, studying the American West in the name of science, had a different effect. Maximilian's survey created a German obsession with Indigenous artifacts. The largest collection of Plains artifacts in the world is housed the in the Ethnological Museum of Berlin (Bolz, 1999). Many artifacts collected in the nineteenth century were gained through theft or exploitation. In turn, the collection likely reflects on the vision of the collectors, rather than understanding the work through ethno-aesthetics. 
Having only narrowly escaped destruction during World War II, the collection consisting of nearly 30,000 North American artifacts lies safely out of reach of the Native American Graves Protection and Repatriation Act (NAGPRA).

Additionally, both of their work was tinted with a form of Orientalism - a colonialist view that exaggerates, distorts, romanticizes, and exoticizes the culture of the colonized (Said's definition pertains to the European colonization of Northern Africa and the Middle East, though this view is applicable with the Americas as well) (1994). The portraiture of both artists depicted Indigenous men as brave warriors, mighty hunters, daring horsemen, and noble savages. These unidimensional images of the warrior loom large in the imagination of Euro-Americans, that it has distorted the understanding of Indigenous men and men's art, by placing special emphasis on military prowess (Berlo \& Phillips, 1998). While scholars such as Brody and Dockstader spent years researching how White encounters affected Indigenous art, few scholars documented how early interactions would shape their history.

\section{The Civil War and Westward Expansion}

There were many factors that contributed to changing styles of Plains art in the second half of the nineteenth century. Artistically, the glass bead trade, introduction of new materials such as paper and canvas, and the inspiration of the works of Catlin and Bodmer (as small as they might be), had an impact on the creation of art. However, there were several cultural influences that shaped the creation of Indigenous art. The civil war, famine, economic hardship, the near extinction of the buffalo, the development of reservations, and residential schools all had a profound influence on the development of art. 
The years following the American Civil War were some of the most traumatic in the history of the Plains people. Exploration and settlement of the Plains boomed, and the U.S. military was now free to focus their attention on westward expansion (Berlo \& Phillips, 1998, Greene 2014). In addition to forced resettlement, Plains tribes, who had been dependent on the buffalo for multiple forms of livelihood, found their source for food, shelter, dress, and tools on the brink of extinction. The transcontinental railroad was completed in 1869 , crossing migratory patterns of buffalo herds and interrupting the nomadic life of the Plains people. This double blow was accentuated by governmental efforts of acculturation (Dockstader, 1974).

Acculturation efforts included banning religious ceremonies, government coopted Christian missionary groups as part of a formal policy of directed assimilation. Residential schools developed, under the direction of Richard Henry Pratt, to "kill the Indian, save the man." This sentiment was argued by Pratt as the benevolent action to be taken in managing Indigenous populations. Pratt, who founded the U.S. Training and Industrial School in Carlisle Barracks in Pennsylvania, addressed the success of his programming in an 1892 convention with the following words:

"A great general has said that the only good Indian is a dead one, and that high sanction of his destruction has been an enormous factor in promoting Indian massacres. In a sense, I agree with the sentiment, but only in this: that all the Indian there is in the race should be dead. Kill the Indian in him, and save the man." - Captain Richard H Pratt

Pratt's practice did not include Indigenous people within the definition of America; he was clear it was at no point an objective of the residential school program to include the "civilized savage" in the nation. Thus the Indigenous people of North America moved into the twentieth century stripped of culture and heritage, stripped of 
religious practices and language, forced onto isolated and desolate reservations, both at once "Americanized" and denied citizenship or civic participation in American government (Official Report of the Nineteenth Annual Conference of Charities and Correction, 1892).

The breakdown of family structure, the imprisonment of thousands of Indigenous figures, and the forced destruction of religion were not the only agents of destruction on the arts (Berlo \& Phillips, 1998). Christion missionaries adopted a diminutive attitude for the traditional arts and crafts being made, and large amounts of arts deemed unchristian, uncivil, overtly erotic, or violent were burned in puritan fires (Dockstader, 1974). This further crippled the economy of the Plains people; no longer able to source their own food or necessities, and imprisoned to small reservations, art had become an intercultural means of exchange between Indigenous artists and white patrons (Berlo \& Phillips, 1998, Brody, 1971).

New forms of art begin to appear under the structure of brutal oppression. Discarded items, such as registers and ledger books, were adopted in lieu of hides and trade blankets (Berlo \& Phillips, 1998). Ledger art was quickly adopted in place of biographical robe paintings, within a book, each page took on the properties of a section of a hide painting (Brody, 1971). In much the same way as a buffalo robe, ledger books were often carried into battle by the artist. During the occupancy of the Plains, many ledger books were taken from the body of deceased soldiers by white victors.

Ledger art begins to take on other purposes, many were created to immortalize records of tribal histories, or verbal traditions, and many chronicled the rapidly changing lives of the Plains people, and some of the most recognized examples were made in 
prisons (Berlo \& Phillips, 1998, Brody, 1971). During the years 1875-1878 several Cheyenne and Kiowa leaders were imprisoned in Fort Marion, Florida. Here they documented the imposing influence of European-American efforts of assimilation, and the challenging identity of straddling both worlds. These illustrations recorded the forced activities of bible study, manual labor, daily class, army attire, as well as the nostalgia for their quickly diminishing culture (Berlo \& Phillips ,1998).

Beading becomes a much more prolific form of art during this time as well. Beading, which complemented and replaced the art of quill work, had been practiced as a decorative art prior to the reservation era, but with the new sedentary life, women found they had more time to dedicate towards craft. While beading had been incorporated into costumery and regalia, it was in the late nineteenth century where fully beaded designs began emerging (Berlo \& Phillips, 1998). Beadwork followed the composition style of earlier hide painting: some were composed in geometric abstractions, some in biographical style, both still contained elements of bilateral symmetry. We begin to see a difference in beading style between tribes. The Lakota adopt a biographical representational style, filling the entire canvas in bands of lazy stitch, incorporating figural and geometric design. Crow work is boldly graphic, favoring large blocks of color, particularly light blue, with shapes outlined in strands of white beads. Influenced by the French, Ojibwe and Cree incorporated floral designs into their work.

Many designs were survival tactics; the overtly harsh influence of Christian majorities dictated that imagery coming out of residential and reform schools should reject signs of paganism and adopt European indications of civility and Christ. Floral motifs disguised what were considered "pagan' beliefs by adopting a modified European 
appearance; the Sun Dance was practiced in secret by adding the cardinal directions to the medicine wheel that it might represent a cross, and decorating Sun Dance regalia in stars and stripes, hosting the dance on July $4^{\text {th }}$ as a celebration of the United States (Berlo \& Phillips, 1998).

Despite the development of highly stylized, bicultural forms of art, Plains art was still excluded from the art market. Instead, collectors lamented this new form of art was a "byproduct of contact-caused culture change" (Brody, 1971, p. 30). "Authentic" or "traditional" Indigenous artifacts, those unaffected by colonialism, became those most prized by collectors. The structural and systemic erasure of Indigenous culture led to an "infatuation with the Indian of the past" (Dockstader, 1974, p. 30). Arts reflecting the oppression, assimilation and Americanization of Indigenous tribes was valueless. Collectors were now interested in the works that had systematically been destroyed in puritan fires. Once again, the Native's narrative was excluded from the economic advantages associated with the extensive ethnographic collections developing in the United States' cultural centers.

\section{The Great Depression and The Santa Fe School}

The Great Depression spurred the growth of artwork nationwide, but included the development of Indigenous art. In order to stimulate economic growth, Indian Commissioners Scattergood and Rhodes formulated a federal policy that intended to enable Indigenous Americans to develop tribal governments, promote self-determination and social welfare, and preserve Indigenous culture (Dockstader 1974, Wheeler-Howard Act of 1934). However, nearly two generations of forced assimilation, geographic restriction, and outlawed religious practices left many communities without a foundation 
to stand on. The Fourteenth Amendment to the United States Constitution, which granted Indigenous people of the United States the right to citizenship, had been passed a mere decade prior. This once again placed Indigenous people in a precarious bicultural dilemma - they could not return to their lives of old, nomadic life was restricted on reservations, and the buffalo had been hunted to near extinction, and many had developed a form of dual-identity, embracing Christianity to various degrees and incorporating it with traditional practices.

The so called "Indian New Deal" included a revitalization of arts and crafts. Though many artists were still alive, few were active, and very few younger tribal members were versed in traditional crafts. Fieldworkers on assignment from the United States government were sent to reservations to document art and craft work (Dockstader, 1974). Much of the art at this time was reduced to the development of trinkets and knickknacks, in effort to drive any economic stimulation. As a result, teaching and creation of fine art all but disappeared.

The Indian New Deal waned shortly after it was implemented. The United States abandoned many of the economic policies implemented in the New Deal as in entered into the second World War in 1941. However, the Wheeler-Howard Act is often credited as initiating the beginning of Native tribal sovereignty.

In reaction to the eradication of most traditional forms of fine arts, a new school of Indigenous art appeared in its stead: the Santa Fe School. This school has a rich dichotomy of both unifying advancements in Indigenous arts, and creating a singular ethno-aesthetic that appealed to Western patrons (Berlo \& Phillips, 1998, Dunn, 1968). 
This modernist style of aboriginal art generated a style that encompassed and conglomerated all North American Indigenous art.

The 'Studio School' established at the Santa Fe Indian School in 1932, was a program developed for young adult participants directed by Dorothy Dunn. A nonNative, Dunn was renowned for refraining from presenting a curriculum in Western art practices (such as still life, perspective, or color theory), and encouraged students to adopt elements of their cultural tradition as the basis of their work (Berlo \& Phillips, 1998). The style encompassed elements of various forms of Indigenous composition, such as heavy outlining, application of flat fields of color, chronicles or narratives, and elements of ceremony, while maintaining stylistic elements similar to many calendric hide-paintings, ledger art, or winter counts. Predominantly, these drawings featured horses, bison, birds, or depictions of reservation life. The result was a fairly uniform, highly styled oeuvre of work that incorporated elements of Indigenous art, and appealed to a non-native audience.

The Santa Fe school was not as culturally disruptive to the development of Indigenous culture as the puritan fires, or the salvage paradigm (an almost frenzied collection of the relics of a culture perceived to be vanishing), but it defined for perhaps the first time in the United States the difference between Indigenous fine art and artifact. This definition was restrictive: work coming out of the Santa Fe school was limited primarily to opaque watercolors, specific themes, and stylistically similar compositions. However, the compositions appealed widely to non-Native audiences. Full of movement and rich Plains color pallets, the paintings depict scenes rather than a complicated series of highly stylized icons and symbols. Despite all the short comings, this art was an 
illustration of the first attempts at a style of bi-cultural art, one that depicted the clear Western influence on Plains artists, while also connecting a predominantly AngloAmerican audience to the Indian experience. 


\section{CHATPER II}

\section{THE GREAT WHITE NORTH}

In stark contrast to the effect colonialism had on the Great Plains, the effects of settler colonialism in the North American Arctic was vastly different. This is largely due to the remoteness of many of these Northern communities, and difficulty in accessing them (many isolated islands are only accessible via boat during the summer, sled during the winter, and inaccessible during the fall and spring as the weather is changing).

The Norse reached the Canadian Arctic nearly 500 years prior to Christopher Columbus' excursion to the Caribbean. Arriving at the Northernmost point of Newfoundland and mainland Labrador, they attempted colonization but found the landscape inhospitable and the people volatile (Crowe, 1974, Hessel, 1998). However, what is commonly called the "contact period" began in the late 1400s and lasted until roughly the end of the nineteenth century (Crowe, 1974).

The highest amount of contact between Indigenous people of the Arctic (Inuit and Algonkian) occurred through extensive trading and fishing networks along the eastern coast of North America (Josephy, 1994). Beginning in the mid-nineteenth century, Inuit (the arctic Indigenous people of Canada) and Eskimo (the arctic Indigenous people of Alaska) began having regular contact with foreigners and established fur trading posts (Hessel, 1998). Much of the colonial history of the Great Plains is mirrored by the colonization of the Arctic: increased trade created a dependency on barter economy, and 
away from a subsistence economy, increased travel through the Northwest Passage aided in the decrease and near extinction of the bowhead whale, and government policies assisted by Christian missionaries began to resettle Inuit communities (Billson \& Mancini, 2007).

However, there are a few key differences that stem mainly from the differences between governmental organization and policy. During the Resettlement Period (roughly 1950-1970), Inuit were displaced by the government not in an attempt to seize land. This was a result of the Canadian supreme court ruling in 1939 to formally recognize the Inuit as Canadian citizens. As citizens, the welfare of Inuit communities became the responsibility of the federal government to assist in governance and assimilations in a supreme court ruling, and consequently it was the role of the federal government to assist the Inuit in adjusting (Hessel 2007, Billson \& Mancini, 2007).

\section{Art of the North}

For the Eskimo to the West, there is a clear distinction between the art created pre- and post-contact. As trade routes and encounters with foreigners increased the creation of Eskimo market art was extremely prolific. The distinction between traditional art and market art was identified by the intended audience. Starting in the 1890s, traders were requesting signatures or other sources identification on works of art as an indication of authenticity and artistry. Much like Plains art, the Inuit had frequently viewed art as an expression of biography, or a representation of myth; including a signature in such work seemed unnecessary (Ray, 1977). 
Of all North American Indigenous arctic arts, Alaskan Natives had the most prolific production, both in traditional and market arts. The gold rush around Nome and Saint Michael drove an economy with a high supply, at the turn of the twentieth century, thousands of objects were being turned out by dozens to hundreds of craftsmen. Traditional art consisted of several spiritual objects such as shamanistic masks, funerary dolls, amulets and charms. Pre-contact art was predominantly three-dimensional masks and sculptures of wood, ivory, bone and stone. Though many of the mediums are used both for traditional and market art, market art often took on additional icons or usages, many were souvenirs of sorts, jewelry, pipes, baskets, and billikens (Buddha-like sculptures, with gnome like features). Much of these objects were created from available resources, particularly walrus ivory, though wood, birch bark, sinew, and fur were employed as well (Ray, 1977).

This economy was dominated by tourism. The gold rush brought hoards of miners (predominantly non-Native) to the Alaskan tundra. As a result, this boom market was dictated by the mining economy, and when the industry burst, the prolific production of artistic goods slowed. Efforts to combat the changing market were implemented in the 1960s as a form of designer-craftsman training. However, with extremely isolated and rural populations, the cost of attendance in terms of missed hunting opportunities and agricultural seasons was enough of an incentive for many to defect from the program. The promise of an eventual return of an economic gain was not a strong enough appeal. Some artists finished the trainings and led successful careers as fine artists, however, the initiative was largely unsuccessful in instituting a new school of fine arts in Alaska (Ray, 1977). 
The Inuit of Canada, conversely, had significantly less interaction with traders in the first half of the twentieth century. Small communities of roughly 40-60 people were scattered across the landscape, and since the failure of English explorer Martin Frobisher to find the Northern passage or return with valuable metals, this region was largely undisturbed with few communities ever coming into contact with trade networks, government workers, or missionaries (Josephy, 1994, Hessel, 1998).

During the resettlement period, the seminomadic lifestyle of the Inuit was disrupted significantly. The government displaced more than 700 camps into roughly 40 communities. Though the communities were small, they contained people from various cultural, economic and social backgrounds, making these spaces approximations of urbanization. Lifestyles, values, gender roles were disrupted, creating a new, amalgamated culture. Additionally, federal resources such as hospitals, schools, welfare institutions, industrialism, and other institutions of Euro-centric design emerged. The disruption from traditional life, and the abundance of social institutions created a social and political dependency (Billson \& Mancini, 2007).

This immediate transition into industrial life increased the amount of dependency the Inuit had on the government; no longer were communities able to hunt for their sustenance, government housing was poorly designed and couldn't withstand arctic temperatures as well as igloos by Inuit design. Like residential schools in the US, those in the North were run by Christian missionaries, and included an agenda to direct youth away from pagan, multi-theistic practices. Many port cities around [the bay] had the capacity for blue collar work in the form of industrial machinery operations, however, the language and skill barrier between the Inuit and Euro-Canadians was too significant for 
safe, gainful employment. Inuit were undependable workers, many of whom still followed seminomadic hunting patterns, and could disappear from the works site for extended periods of time. It seemed that the lifestyle of the Inuit was incapable of cohesion with the modern world (Crowe, 1974, Hessel, 1998).

\section{$\underline{\text { James Hudson and Dorset Fine Arts }}$}

The practice of Inuit commercial art began in Cape Dorset in 1948. Towards the beginning of Canada's resettlement period, a young artist named James Hudson journeyed into the Quebec Arctic to complete a series of paintings, portraits and landscapes of the people he encountered (Hessel, 1998, Ray, 1977). In his encounters he was offered ivory carvings in exchange for sketches. The sculptures he returned with caught the eye of members of the Canadian Handicrafts Guild in Montreal. The guild supported the idea of expanding Inuit craft, and supplied Hudson with funding to secure objects of exemplary craftsmanship.

The fundamental difference between this collection of Inuit sculpture and that of the Great Plains is that Hudson's collection did not include the presence of the salvage paradigm; the arctic was vast, largely uninhabitable to Westerners, there was no concern of Inuit culture disappearing. In fact, it is undisputed that Hudson intentionally acculturated Inuit work. The system of resettlement provided very few economic opportunities for the Canadians of the arctic, and as new citizens, the government needed the Inuit to stay in the new semi-urban settlements they had created (Hessel, p 34, Department of Northern Affairs and National Resources, 1954). Hudson's acculturation assisted on both fronts, artist Osuitork Ipeelee recalls: 
"Before the government came up here there was only one way of making money. People could make money from fox furs and the other things we used to bring in, but only a little money. Then it was learned that carvings here in the Arctic have a price and when there were no jobs available people quickly learned their value. That is why they have tried so hard at it. If people hadn't started carving we'd all be supported by the government." (Eber, p. 425, 1993)

What then was the difference between the carvings of the Alaskan Eskimo and the Canadian Inuit? Both artists were aware they were creating work for an audience other than themselves, both accepted and incorporated foreign influence. Balancing individual expression and artistic compromise, both groups sought economic gain by appealing to outside influence. The difference came in the priority for success for both these markets; the US is a highly individualistic nation in terms of governmental policy, the Alaskan gold rush, and the economic boom it inspired was viewed as a mineral resource economy, as the resources dwindled the government felt no responsibility in developing policies that would sustain Eskimo craftmanship or economy. Canadian federal policy would provide the Inuit with welfare services that were provided to all citizens. Establishing a long-term economy was largely beneficial to the expense of the crown.

\section{Cape Dorset Print Collective}

The story of the beginning of the West Baffin Island Eskimo Cooperative at Cape Dorset has gained an anecdotal notoriety in its retelling. On a winter night in 1957, James Hudson sat with an Inuit sculptor, Oshweetok Ipeelee, and his friend. Oshweetok was observing the trademark sailor on two cartons of cigarettes. After a time, he acknowledged it must be exhausting for an artist to recreate so precisely each image. Hudson began to explain in limited Inuktitut the process of printmaking. His description 
was not all together successful; he had limited knowledge of Inuktitut and was pressed to find the words describing the intaglio process and color register. In looking for props to better explain the processes, Hudson demonstrated on an ivory tusk recently engraved by Oshaweetok. Hudson spread a thin layer of writing ink across the smooth surface of the ivory and imprinted the matric on a piece of tissue. In observing the full process, Oshaweektok stated "We could do that," and the cape Dorset print collective was born (Husdon, 1967, p. 10).

Though much of Hudson's writing on the origins of the cooperative are allegorical, and contain a "mystique of false conception" (Ray, 1977, pg 59), there is no historical record from Oshweetok chronicling the origins of the Baffin Island collection, and there are certainly elements of oversimplification or exaggeration in elements of Hudson's retelling. There is some variance within Hudson's own account, and select narratives are omitted in the literature. There is no doubt his influenced helped establish one of the most successful Indigenous cooperatives in the world. It is also evident his allyship was crucial to the success of the Baffin Island Cooperative. Several other Inuit communities developed cooperative studios after the successful model in Cape Dorset, but many failed to take off, with collections routinely rejected by the Canadian Eskimo Arts Council's jury (Hessel, 1998). This included a sculpting cooperative in Puvirnituq, the Holman print collective (which was mildly successful in printmaking, but developed nowhere near the sustainability of Baffin Island), a government run print studio, Pangnirtung, which lasted only 15 short years, and Baker Lake. Baker Lake was renowned for their appliqué and textile arts, thus the government supported a graphics program in the Kweewatin community, like many of the other government cooperatives 
Baker Lake would have had only mild success if it weren't for the arrival of Jack and Sheila Butler (Hessel, 1998).

Weary from the failed governmental programs, and years of poverty and famine due to the efforts of resettlement, little talent remained in the Baker Lake community, and enthusiasm for Butler's efforts to revitalize an artistic cooperative were lackluster at best. The Butler's initiated a printmaking project and sewing project where a failed garment industry had existed, and were eventually able to expand and establish the Sanavik Cooperative, developing Baker Lake as the capital of Inuit textile arts (Crandall, 2005, Hessel, 1998).

Few scholars write about why the alliance of white artists was crucial to the success of Inuit and Eskimo arts. The art of the Alaska Native never made it past curio and souvenirs, even though style, composition and skill were near identical to objects made in Eastern Canada. Conversely, the tapestries and wall hangings produced at the Sanavik Cooperative bypassed the label of "craft," and was accepted as a fine art form as early as the 1980s (Hessel, 1998).

\section{Modern and Post-Contemporary Inuit Art}

One of the of the exceptional aspects of Inuit art is the nearly seamless blend of traditional and imperialistic life. Because Inuit art did not fall prey to the salvage paradigm, criticism of presentation for a non-Native audience was relatively reserved. Artistic alliance and sponsorship, in the form of both James Hudson and Shiela and Jack Butler, was tremendously beneficial to the longevity and stability of the Northern art market, and while their influence is certainly evident, it did not compromise Inuit artistic 
tradition or representation at the same level as Southern contemporaries such as Dorothy Dunn. In most cases the influence of the foreign artists was supplemental rather than detrimental, unlike the perception of Dorothy Dunn's impact on creation of Plains fine art.

The West Baffin Island Eskimo Cooperative was successful for a number of reasons, but among them were strong aspects of bi-culturalism. For years fine arts in Cape Dorset had been dominated by men; sculpture was largely considered men's art, while other craft arts such as sewing and applique, and traditional tattooing (in the skin stitch method), were recognized as women's arts. As a result, sculpture and early prints were dominated by images of hunting (Hessel, 1998). Printmaking at Cape Dorset largely followed Japanese style ukiyo-e, wood block printing. Inuit innovation and available resources (timber notoriously does not grow well on the tundra), led to a style in which sculptors would cut graphic images out of slate. This resulted in a matrix that was capable of producing hundreds of prints. While stone cutting had been dominated by men, Hudson saw an opportunity to expand the creation of graphic images, and recruited many women to participate in printmaking as well.

Including women in printmaking provided supplemental economic benefits. Separating the graphic artists from the stone cutters allowed for more efficient use of the limited studio space. Women contributing to the graphic design of the works were able to maintain a semi-nomadic life: traveling along seasonal migratory hunting paths with their family, while maintaining financial stability. Many female artists had participated in art making, though they tended not to include graphic arts. Stylistic elements from textile art, decorative art, skin stitching (a style of tattooing in which the artist stitches sinew coated 
in fat and fine ash, under the dermis), served as inspiration to produce images for sculptors to stone cut. This promoted a wider array of draftsmen (and women) to produce images, and also addressed the spatial limitations that prevented all artists from learning to create their own printing blocks (Hudson, 1967, p. 22).

This strategy not only led to new innovations in Inuit print making, it led to the development of some of Cape Dorset's most notorious artists, including Kenojuak Ashevak, the most recognized figure in Northern fine arts. In the forward to the Baffin Island catalogue in 1993, Ashevak recalled:

"I will never forget when a bearded man called Saumik [James Hudson] approached me to draw on a piece of paper. My heart started to pound like a heavy rock. I took the papers to my Qamak and started marking on the paper with assistance from my love, Johnniebo. When I started to make a few lines he smiled at me and said "Inumn," which means "I love you." I just knew inside his heart that he almost cried knowing that I was trying my best to say something on a piece of paper that would bring food to the family." (Ashevak, 1993)

For Ashevak, the opportunity to participate meant she could assist in providing for her family, while her family could follow semi-annual nomadic hunting patterns. Ashevak kept a small collection of papers and graphite with her, and upon return to Cape Dorset would present her work to stone cutters (Feeney, 1963). Women's decorative arts also leant themselves to the development of print making. Inuit women versed in applique would gather scraps left behind from sealskin, these figures were often examples of fauna and flora. Once dry the seal skin was stiff and impermeable, but when wet the material was malleable. Not a culture of waste, many of these scraps and cut outs were saved and used to illustrate old stories and fables for children. When following hunting paths, Inuit would dampen the cutouts and place them on the snow walls of the 
igloo where they would fasten (Hudson, 1967). In observing the sturdiness of the material, in addition to its water-resistant property made the material ideal for stencil making.

Inuit stone cut and stencil are highly stylistic and instantly identifiable. Variances between each region of the Canadian and Alaskan Artic is discernable, though there are many characteristics that unite the genre. In the mid twentieth century images focused on abstract images of animals, mythical deities, and to a small extent, humans. Sculptures, a predominantly male medium, often featured hunting scenes, or historic events. Contemporary art (that developing after 1949) includes many of the same elements but adds more pastoral scenes: Inuit games, landscapes abstract portraiture. Many women elected to capture the facial tattoos of their elders which had once been a strong feature of their culture. The expansion of Christianity had forbidden the practice of tattoo as a heathenistic practice. Recalling the tattoos of their elders was a way of preserving the systemic erasure of traditional life (Hessel, 1998).

Later artists addressed many of the symptoms of forced resettlement: addiction, abuse, rape, poverty, racism, and a hybridization of Inuit and Canadian life. Having developed in a manner that offered economic opportunity and gains to newly urbanized communities allowed artists to address these issues without the shroud of anti-Indian art that plagued many creatives in the United States. 


\section{CHAPTER III}

\section{COLLECTION AND CURATION OF INDIGENOUS OBJECTS}

Viewing Indigenous art through a western lens requires an amount of cultural competency on behalf of the audience that is rarely taught within American art appreciation or history. For the most part, Indigenous arts fall outside the Western definitions of fine arts, and frequently bridge fine art, craft, performance art and spirituality. In this regard it is also challenging to define artifacts as solely utilitarian, sacred, or decorative; often they embody all three. Many of the problems in curating Indigenous objects stem from Western paradigms in the collection (Berlo \& Phillips, 1998).

For Western collectors, there were several factors that influenced the curation, commission, collection, and valuation of Indigenous works. As a function of colonialism, many collectors feared that Native cultures would vanish from the American landscape, whether from assimilation or cultural extinction. This led anthropologists to develop extensive collection with urgency, in an attempt to salvage remnants of the "weaker" cultures (Lowman, 2018). This paradigm has shaped ethnographic collections worldwide, has influenced the narrative of curation, and has provided a narrow lens through which cultures are observed and understood.

The salvage paradigm has been one of the predominant factors shaping antiIndianist perspectives in art. The perception of portraying Natives as culturally inferior to Western settlers has had an equally adverse effect on non-Native perceptions, as well aa Indigenous depictions of culture, in effect completing the cycle of colonialism. While racism, sexism, multiculturalism, and diversity are frequent topics of discourse for 
historians, artists, curators, collectors, the term "anti-Indianism" is seldom employed. Addressing institutional anti-Indianism within both history and art (two disciplines which have a record of claiming to be ethically neutral, or at least ethical meritocracies) would require an earnest evaluation of deep-seated, self-congratulatory colonial power dynamics (Cook-Lynn, 2001). It also causes one to address the tremendous cruelties that are the consequence of Western occupation.

This sentiment was summarized by Catherine Drinker Bowen in an article appearing in the New York Times:

"I have never liked to think about American Indians. I am not proud of the way we have behaved toward them, and I would rather read about something else. John Adams, as I recall, did not like to think about

Indians either" (Dockstader, 1974, p. 49)

This type of malignant apathy has plagued curators, critics and creatives, as a fundamental cornerstone of anti-Indianism it prevents institutions from working towards decolonization. As with other types of predominantly Western settler colonialism, creative works created under these terms are akin to Said's Orientalism. That is, European-Americans and Canadians have created a romanticized perception of Indigenous life and art, and as the dominant culture, it is near impossible for marginalized groups to reclaim their narrative. The narrative set for in North America is reinforced through literary works, arts, and understandings of archaeology and anthropology (still dominated by white men). The American West that appears either through representation, curation, or historic presentation is one that is framed by a Western understanding of consciousness, learning, and civilization (Said, 1994). In the same way, anti-Indianism 
provides Westerners an imperialist, ethnocentric, and racist narrative in understanding bicultural relations with the Indigenous peoples of this country.

While examples of white anti-Indianism are common (one has only to look at the literary works by authors such as Louis L'Amour and James Fenimore Cooper, or artists such as Russ Dockens or Sharon Cummings), the backlash it has on Indigenous communities is equally if not more significant. For Native artists, producing work for predominantly white audiences allows artists to legitimize their work by being accepted into the western canon, at the expense of de-legitimization of the subject matter (CookLynn, 2001). Often this leads to work saturated with elements of self-hatred; this can come in the form of rejection of culture and tradition, adoption of Euro-centric features, and the adoption of the male gaze which reinforces colonialism's reliance on a patriarchal foundation (Qwo-Li, Finley, Gilley, \& Morgensen, 2011). This may be observed in works by artists such as Tim Nevaquaya, Marlena Myles, and Robert Martinez, whose work depict tradition and culture stylized to appeal to a European pallet. While adopting a Euro-centric style is not inherently anti-Indian, the way in which these artists shift the focus of the work to the aesthetic aspect of their heritage, the delegitimize the significance of their culture. The subject of many Indigenous artists may be the extreme poverty and violence that are a result of reservation life and multiple generations of trauma. The expression of such themes is not inherently anti-Indian, the adoption of popular language or culture, one that exploits the experience to appeal to non-native audiences contextualizes anti-Indianism (Cook-Lynn, 2001). Literary artists such as Adrien Louis and Alexie Sherman have both been complicit in the promotion on antiIndian sentiment. Writing about the violent effects of poverty and inter-generational 
trauma can be a source of healing for many creatives and audiences, except when the finished work comes at the expense of delegitimizing the origin and experience of those depicted.

In an interview with Navajo printmaker Melanie Yazzie, she lamented how younger artists in particular were suspect to this trap. "I meet with young people, young men who are doing paintings of white women models with headdresses, and I ask them 'Why are you doing that?' It's what sells, it's what people want." Without mentorship or guidance, a lot of developing artists will produce for curators, or for audience, creating work that results in stereotypical anti-Indian narratives (personal communication, October $\left.29^{\text {th }}, 2018\right)$. The Dorsey Dunn style of work was also complicit in promoting this sentiment. While her teaching style helped bridge a bi-cultural gap in the collection and value of Indigenous fine art, it came at the expense of inauthentic representation, and exploitation of Native aspects of life. That Dunn's work continues to have varied critique and reception is a strong indication of how subtle anti-Indianism can be.

\section{Collecting the Vanishing West}

The West, and the Great Plains in particular, has a fraught history with the collection (often forcible) of artifacts. In observing the collection and exhibition of Indigenous artifacts, one institution in particular stands out: The early twentieth century Brooklyn Museum in New York City.

The Brooklyn Museum's Zuni collection began with the ethnologic research of Frank Hamilton Cushing. In 1903, the Brooklyn Museum (formerly the Brooklyn Institute of Arts and Science) developed their Department of Ethnology. This department 
was entrusted with collecting the "works of men on the American continent exclusive of those by people of European descent who have come to America since 1942” (Berlo \& MacDonald, p. 64, 1992). While this description generally applies to Indigenous peoples, it is undoubtedly problematic. Contrary to popular belief, nearly half of the North American Indigenous population is mixed race, a trend that has been prevalent since first contact, strengthened with the diaspora of freed slaves in the nineteenth century (Nittle, 2018). This definition excludes any work created by Indigenous tribal members who have a background shaped by the effects of colonial intervention.

Throughout the nineteenth century, anthropologists developed a method of collection that encapsulates the belief that it is necessary to preserve marginalized cultures from destruction by the dominant culture: the Salvage Paradigm. This was the basis of many ethnological collections, including the Zuni collection at the Brooklyn Museum. This paradigm led collectors and curators to value pre-Colombian art, or work uninfluenced by settler colonialism, over art or craft that represent the culture and histories of North America's first people.

The Department of Ethnology was particularly susceptible to this fallacy. Under the direction of Stewart Culin, whose interests were "remarkably broad" and included Chinese Secret Societies in the US, Street Games of Brooklyn, and Primitive American Art, the collection of Indigenous artifacts began in 1903 (Berlo \& MacDonald, 1992, p. 65). Culin's objective was to establish a collection of objects that he could coax into telling a story to the world, he called this philosophy the "language of things." Armed with this narrative, Culin sought to amass the world's most significant collection of Zuni 
artifacts, a task previously assumed by his personal friend Frank Hamilton Cushing (Collwell, 2017, Berlo \& MacDonald, 1992).

Cushing was an ethnographer, who nearly 25 years prior to Culin's own endeavors, had been assigned by the Bureau of Ethnology to undertake a study of the United States' Southwest. Cushing arrived at his first destination, Zuni City, and stopped there. These people, he marveled, were the "Indian of Indians" (Berlo \& MacDonald, 1992, p. 67). Rather than continue his ethnographic observations, Cushing became a permanent resident of Zuni City, adopting Zuni-style dress, learning the language, he was even initiated into the Priesthood of the Bow. After five years, he returned to New York where he performed his experience of Zuni City, in what he coined "participant observation" (Berlo \& MacDonald, 1992).

Culin was inspired by Cushing's participant observation. His performances were evocative and played well to a predominantly Western audience in New York. After Cushing's passing, Culin was inspired to journey West to complete Cushing's experiment. However, Culin makes no attempt to integrate, rather he is posted himself in Zuni City with the sole focus of documenting the "vanishing Indian" (Berlo \& MacDonald, 1992, p. 69). Armed with the budget of one of the largest historical institutes in New York City, and the cultural competency of one man's participant observation expertise, Culin seeks what he believes must be salvaged as the remaining relics of a dying culture: Old Things.

His tenacity to collect remaining Zuni relics led him to proclaim himself the "Master of the art of collecting," the Zuni nickname him Inotai, Old Thing. (Berlo \& MacDonald, 1992, p. 73, Colwell, 2017). In this, Culin was successful; his persistence 
and funding allowed him ample opportunity to purchase objects, knickknacks, agricultural tools, weapons, games, and instruments. In 1903, Culin's first year collecting in the field, he brought home more than 4000 objects (Batkin, 1987). This was not without consequence on the city; Zuni city had a population of roughly 1,500 , and due to a smallpox epidemic followed by drought, and the forced surrender of more than $80 \%$ of their land, many of the people looked to unload unwanted items for economic gain.

"[The Zuni women] brought me many things that men would not sell” wrote Culin in a report of his expedition, "things which they had gathered in dark inner rooms; things long disused, of which they did not know the significance of value" (Brooklyn Museum Archives, 1904, p. 89). However much value Culin believed he was collecting, he was still unable to acquire what he most wanted: sacred objects (Colwell, 2017). The Zuni were unwilling to part with such significant objects as funerary dolls and masks. Despite the high demand for such objectsfew were willing to sell such objects, unhindered by the sacred or spiritual significance of such objects, Culin turned to three artists in the city and commissioned 75 dolls and 23 masks (Berlo \& MacDonald, 1992). However, by the end of Culin's collection in the field he secured thirteen Ahayu:da,Zuni deities often referred to as Keepers of the Sky (Colwell, 2017, p. 22). This is the largest collection in the world.

The effects of Culin's exhibition extends beyond his deceit and exploitation of the Zuni people. The Brooklyn museum's Zuni exhibition, unveiled in 1907, was modeled predominantly after Cushing's field work, and was less about the ethnography of the Zuni themselves (Berlo \& MacDonald, 1992). This exhibition and collection has been a legacy for the Brooklyn museum, but generations later critics have yet to address the 
controversies of Culin's work. In a 1992 review of the Brooklyn Museum's Objects of Myth and Memory, featuring heavily from Culin's Zuni collection, Alice Horner lauds Culin's experience. "Never formally trained in ethnology, he is best understood as one of that generation of gifted amateurs" (Horner 471). This extensive collection, relics of what Culin believed were the "vestiges of a vanishing race" (Honer 1992, p. 471, Berlo \& MacDonald, 1992, p. 14, Colwell, 2017, p. 17), is so intertwined with the narrative that Culin imposed upon each object, that nearly a century later it is hard to extract.

For other institutions collecting and curating content at this time, such as the Smithsonian and the Peabody, Culin's fanatic, frenzied, and complete assumption of artifacts led to somewhat of a collections arms race (Colwell, 2017). Furthermore, the ethnographic departments of the Untied States most admired institutions were founded on a practice that was questionably ethical, in a manner that completely removed Indigenous narratives surrounding creating, culture, history and heritage from the understanding of the artifact.

This style of collection and exhibition, developed at the turn of the twentieth century, has been the bedrock for collecting North, Central, and South American Indigenous work. Institutions like the Peabody Museum and the Smithsonian Museum of the American Indian based many of the exhibitions on, or as an extension of Culin's legacy. The Native American Graves Protection and Repatriation Act (NAGPRA) of 1990 was largely a reaction to this model of collection. Objects collected through exploitation, theft, or taking advantage of desperation have created a lasting legacy of pain for Indigenous communities and Native museums goers. Only recently have 
institutions started working actively towards repatriation of objects, and recontextualizing exhibitions to include Indigenous perspectives.

\section{The Indigenous Art Market}

Much of the Southwest had realized the economic value their antiques had for historic organizations, but as these supplies depleted many craftsmen began to seek additional means to support their development. During this time, at the turn of the twentieth century, there was a significant economic boom in the commoditization of

Native art. By the end of the nineteenth century, residential school policies suppressed the development of traditional arts, while encouraging utilitarian handicrafts. New sedentary lifestyles that accompanied life on the reservation provided more downtime and opportunities for alternative economic outlets (Wade, 1981, Berlo \& MacDonald, 1998). Decorative objects of Native design become commonplace in American parlors, and traders and collectors begin seeking out Indigenous art.

Indian art fairs develop in cities such as Santa Fe, where there is a demand for Indigenous craft. Items such as woven blankets, baskets, and jewelry, are extravagantly popular. Art provides leverage for the economic development of marginalized communities. In most supply-demand markets, the producer must make their product suitable to the taste of his patron or risk going out of business; the Indian market falls victim to a double bind in terms of the demand of the market. By developing goods to a non-Native audience, Indigenous craftsmen are bound to the taste of their audience. Consumers of commercial art become the experts of the medium, and in canonizing the curio and knickknack objects, Anglo patrons restrict innovation. 
This market, which is fundamentally based in stereotypical, purist vision of Indigenous works, was built on imperial policies and embodies anti-Indian sentiment that carries over into contemporary valuation and curation of Indigenous work (Cook-Lynn, 2001, Wade, 1981). For the first time in a complication history with collection and valuing fine art, a market economy emerged that began to end the exploitation occurring under ethnographic directives, and created the foundations for establishing a fair and beneficial market for art and craft.

\section{Museum Decolonization}

Nearly a century of exploitative practices, frenzied collection of vanishing cultures, coupled with genocide, diaspora, immense poverty, violence and anti-Indian sentiment, museums rarely reflect an accurate ethnology, anthropology, or history of American and Canadian Indigenous people. "Museums can be very painful sites for Native peoples," Amy Lonetree argues, "as they are intimately tied to the colonization process" (2012, p. 1). Not only are many of the objects gained through extortion or theft, much of the curator narrative excludes Indigenous voices. Institutions that house Indigenous work have to navigate between representing the history and context of a work, or let the visual medium stand on its own (Ostrowitz, 2009). This dichotomy excluded Native canonical work form the "gate-keeping" institutions.

These types of institutions typically fail to address the truths of colonialism, and present artifacts as plunder. Anti-Indian rhetoric employed by curators frequently robs items of their cultural significance, displays sacred items insensitively, or incorrectly places value on objects that are attractive to non-native audiences. The idea of 
decolonizing a museum addresses sensitivity in exhibiting and handling Indigenous artifacts, as it does creating a space for healing.

What does decolonizing an institution look like? Since museum decolonization as a field is somewhat new, there is no precise model that can be observed, particularly in the United States, which represents more than 500 Indigenous Nations. For current organizations, there are three areas in which decolonialization efforts can take place: collecting, curating, and reception.

In recent years, strides have been made towards decolonizing collections, much of this came in the form of legislation. NAGPRA has helped in returning many of the objects that were collected through unethical or unconventional means: the thirteen Ahayu:da collected by Culin, for example, have been returned to the Zuni (Colwell, 2017). The act by no means goes far enough, it covers items within the United States, items that have no proof of acquisition, and museums are not required to be NAGPRA compliant. Additionally, the return of tribal artifacts isn't always black and white. It is not uncommon for tribes to gift artifacts to institutions, "Gift giving is really important [to Native culture]" Indigenous Archaeologist Emily van Alst told me, it isn't uncommon for tribal leaders to gift significant objects to institutions (personal communication, August 29,2018). There are even cases where tribes may request specific artifacts, particularly funerary objects, be removed from display, but continue to be preserved by the museum.

Upon opening, the Lakota Dream Museum \& Monument wrestled with whether or not to obtain 501(c)3 status. Executive Director Adonis Saltes recognized that in the case of dissolution, if his organization was a for-profit institution he would be able to 
maintain ownership of purchased artifacts, however with 501(c)3 status he would be required to give his collection to a different existing 501(c)3, such as the Oglala Tribe "The tribe doesn't have the resources to care for such sacred items. These items are sacred, and I want to make sure they last for hundreds of years," (personal communication, September 20,2018). Tribal council is not established to preserve spiritual artifacts, and as with any governmental system, there is a continual change in leadership. As the only Indigenous-owned museum in the Black Hills, there was no other organization with whom the Lakota Dream could entrust the preservation of sacred artifacts. The Lakota Dream Museum is unique in that it seeks the council of tribal leaders for the display of every item in its care. Should the organization dissolve, there is no guarantee that this aspect of their biography is retained.

Ethical collection is not just a woe of the past. In order for collections to address anti-Indian sentiment, equitable practices need to be addressed in the collection of contemporary art as well. The salvage paradigm created an extensive collection of protohistoric artifacts, some spiritual, some utilitarian, and some historical, and work coming out of the Santa Fe School in the mid twentieth century found a home in many gallery spaces. The Santa Fe school Studio Style art proved popular, the two-dimensional style paid enough homage to historic expressionism that works were clearly identifiable as Native, yet aesthetically, they were similar enough to trends in art deco to be attractive to a wider, non-Native audience (Berlo \& MacDonald, 1992, Wade 1981). This practiced allowed Indigenous artists to participate in the broader American art market, however came with a price: this art was confined to a style and subject matter that were perceived as authentically Indian. 
However, there is a discrepancy in the collection of Indigenous historic expressionism, modernism, and individualism. Native American modernist works are highly recognizable, and have been included in many collections and exhibitions of American art; Fritz Scholder's incorporation of large swaths of bright colors and American flag motifs lend his work a pop-art appearance while featuring identifiable Indigenous figures. Joe Herrera, perhaps less recognizable to the common eye, mixed elements of the Studio Style and cubism, using a color palette indicative of Studio Style work.

Individualism has fallen prey to a similar critique as Indigenous art of the late nineteenth century: it is not identifiably Indian enough. Oscar Howe, who was trained in the Studio Style, started working in a "highly innovative modernist style," (Berlo \& Phillips, 1998). His subjects were not clearly identifiable as Native, nor were his color palettes or mediums (Wade, 1981). Upon being rejected from the 1958 Philbrook Annual Native juried art exhibition for submitting work that did not adhere to the style acceptable for Indigenous artists at the time, Howe stated:

"Who ever said that my paintings are not in traditional Indian style has poor knowledge of Indian art indeed. There is much more to Indian art than pretty stylized pictures... are we to be held back forever with one phase of Indian painting, with no right for individualism, dictated to as the Indian always has been, put on reservations and treated like a child, and only the White Man knows what is best for him? Now, even in Art, 'You little child do what we think is best for you, nothing different.' Well I am not going to stand for it." (Berlo \& Phillips, 1998, p. 221)

After this incident the Philbrook began to reconsider their definition of Indigenous art, but elements of this perception still persists 60 years later.

This pattern of rejection and gradual acceptance has been repeated for nearly 150 years. Reservation life depleted many of the traditional forms of self-sustenance, and 
though residential curricula had suppressed forms of art-making, the increased amount of idle time and the desperation for a source of economic development led to an increase in the creation of art at the expense of the traditional audience (Berlo \& Phillips, 1998). While one must not conflate the demand for Indigenous knickknacks with the development of fine art, it is undoubtable that economic suppression influenced the success of the development of the canon.

This is a problem faced by Indigenous creators worldwide. While Aboriginal Australian art has recently made its way into the fine art market, Aboriginal artists are still severely under compensated. Contemporary Aboriginal arts in Australia generates $\$ 100$ million annually, yet $50 \%$ of artists are compensated less than $\$ 7,500$ per year (Clarke, 2008). The art market benefits from both resale royalty and a controlled supply of quality Indigenous work, and thus operates in a manner than suppresses the outcome of Indigenous creativity, and limits economic opportunities for marginalized artists.

\section{The Art of Curation}

Curation of Indigenous artifacts still remains a challenge in the United States. Many collections are built on an ethnographic study of Indigenous work, and therefore tend to exclude contemporary works of art. Working within these restrictions, curators often develop exhibitions that romanticize a "pre-modern" lifestyle, or present work that tends to be predominantly ethnographic, even in institutions that focus on the exhibition on modern and contemporary art.

After his infamous 1903 Zuni exhibition, Culin debuted a new arrangement of the Zuni collection: The Rainbow House. Opening in 1920, this collection featured artifacts 
from Africa, Oceana, Asia, and the Southwestern United States, amassing tribal artifacts from all over the world into a single hall. Here, in what he would refer to as his most artistic exhibition, Culin displayed each culture against a background color that "evoked it's essential characteristic;" Zuni was assigned pink, a symbol of dawn. Again, the portrait of Cushing was the focal point of the exhibition (Berlo \& MacDonald, 1992).

From a modern perspective, this style of curation is concerning: not only does it erase the history and context of the object, the narrative developed by the curator himself is one of imagined empathy. Despite the fact that Culin spent years in the Southwest his objectives were based on the observations of a single individual, and reinforced through the objects he collected. Anthropology was a relatively new field at the time, and was dominated by Anglo-Americans.

This raises further questions: should objects such as these be granted to nonNative institutions? Are non-Native collectors or curators capable of conserving and displaying these objects in a way that respects and acknowledges Indigenous history? "Each object has its own history and its own biography, and so I think what's really important for non-Native curators ... is thinking about that biography and giving a full voice to the object."

\section{d'Harnoncourt and the Affinity for the Primitive and the Modern}

After Culin's lauded exhibition, early twentieth century curators in New York attempted to match his success. In 1933, MoMA unveils "American Sources of Modern Art," and exhibition that attempts to draw affinity between Azetec, Mayan, and Incan historical art, and western modernism (Berlo \& MacDonald, 1992, p. 192). However, it 
was MoMA's 1941's “Indian Art of the United States” curated by Rene d'Harnoncourt that altered the American perception of Indigenous art.

d'Harnoncourt's exhibition came on the coat tails of the Indian new deal and significant development in the production of cultural objects. His objective as a curator differed from preceding Native exhibitions in that he aspired to display objects in an artistic context, lauding the aesthetics of the works, rather than in an ethnographical context. He presented a strategy to market Indigenous craftsmanship by appealing to the American sensibility of modernism.

In 1939, d'Harnoncourt successfully employed this strategy in tandem with the Indian Arts and Crafts Board at the Golden Gate International Exposition in San Francisco. The scope of this exhibition was ambitious: d'Harnoncourt wanted to display ancient Indigenous artifacts in an aesthetic way, he wanted to make historic objects understood, and wanted to place contemporary works within a modern setting that would reiterate their value as contemporary objects. That is, his exhibition strategy was to decontextualize ancient art, contextualize historic art, and recontextualize contemporary works (Berlo \& MacDonald, 1992). To do this, he constructed two units: a modern style American house, and a pueblo, placing artifacts within both so audiences could contextualize the making of the objects as well as visualize their modern relevance.

d'Harnoncourt recognized that assimilation policies were disadvantageous for the Native population. He recognized, unlike many of his peers, that the Native had a future in the United States, and that it was crucial to develop a market to assist in the economic rehabilitation of Indigenous arts. To this extent, his immersive exhibition in San Francisco was successful. By the exhibition's closing in October of 1939, approximately 
1.5 million people had experienced d'Harnoncourts immersive display (Berlo \& MacDonald, 1992, p. 206).

That same year, d'Harnoncourt began work towards "Indian Art of the United States," a monumental exhibition, to be realized at the MoMA. He recognized that the timing and location of this event would provide him the opportunity to market Indigenous work as an aesthetic essential to the American canon, and to this point as much a focus was placed on the marketing of works as on the curation itself. In this exhibition, the objects were displayed in a modern fashion. Paintings, ceramics, and sculpture were displayed for their aesthetic value only, display stands were minimal, wall text largely absent, recalling a "dignity usually associated with the works of the Classics" (d'Harnoncourt to Barr, November 8, 1993: IACB 34). Lighting for many of the objects was dark, mimicking the context in which it may have originally be seen, while creating a dramatic, premodern context for such objects.

The entire exhibition was united in a "clean, streamlined look of contemporary design," a juxtaposition of the primitive and the modern (Berlo \& MacDonald, 1992, p. 213). In marketing the affinity for this work, d'Harnoncourt's objective was to present pieces in such a manner that they would appeal to the modern aesthetic, in a way that would generate a new and sincere interest in Native arts. To this end, he placed heavy emphasis on marketing the value of Native contributions to design and style. The entrance of the museum was altered, as d'Harnoncourt placed a commissioned Haida totem pole against modern façade of the MoMA, Swiss fashion designer Fred Picard was supplied with Indigenous artifacts, and created a hybridized line of women's fashion which was featured in the exhibition, and the giftshop featured traditional objects that had 
an appeal to modern Americans: where beaded-sole moccasins were seen as impractical, new moccasins with minimal decorative adornment were commissioned for sale.

The exhibition was received favorably. The modern contextualization of primitive work proved that Indigenous work was a vital aspect of American art, and highly adaptable to modern sensibilities. d'Harnoncourt's mission to stimulate a cultural rehabilitation of the Native American, despite his intention, failed. The exhibition did not promote development or collaboration, but rather a cultural assimilation of curio and knickknacks; an extension of previous trends in native craft marketing. His success lies within the exhibition design itself, this model has become the standard practice in displaying "primitive" and Indigenous work. This show laid the groundwork, and consequently inspired successive show, such as Primitivism in 20th Century Art: Affinity of the Tribal and the Modern.

\section{Primitivism: The Tribal and the Modern}

Nearly 45 years after the rousing reception of Indian Arts of the United States, William Rubin set to approximate d'Harnoncourt's successes. Adapting d'Harnoncourt's concept of the affinity of the primitive and the modern, Rubin morphed the concept from juxtaposing tribal artifacts against modern exhibition and architecture, to comparing tribal works to Western masterpieces. Reception at the time tended to focus on the relationship between tribal work and the influence it had on great contemporary artists.

Rubin followed d'Harnoncourt's example of stripping away the context by presenting work without labels or wall text. However, unlike his predecessor, it was clear Rubin was not driven by the desire to stimulate a rehabilitation of tribal or Indigenous 
work. While reception was generally favorable, Thomas McEvilley, then editor of Artform, wrote of the exhibition:

"Western egotism still as unbridled as in the centuries of colonialism and souvenirism. The Museum pretends to confront the Third World while really co-opting it and using it to consolidate Western notions of quality and feelings of superiority." (McEvilley, 1992)

Rubin's presentation placed Indigenous works in a space where they were not only decontextualized, but displayed in a manner which promoted comparison and the conclusion of Western superiority in art. Self-evident exploitation of tribal arts became an aspect of modern curation, and while McEvilley's criticism brought this to the forefront, it had no fundamental impact on institutional practices of curation, as evidenced by Magiciens de la Terre, debuting a mere 5 years later. Magiciens, opening in 1989 at the Grande halle del Villette, attempted to address the reoccurring pattern of exhibiting contemporary art from a mere $20 \%$ of the global population (Hou, 2014). To address this, curator Jean-Hubert Martin created an exhibition with works featured equally by Western and non-Western artists. While his intention was to dismantle the perception of Eurocentric superiority in art, however the exhibition was still displayed within a colonial context. This often meant the aesthetic aspects of Indigenous work was prioritized over the cultural significance. Joe Ben Junior, a Navajo artist created a sandpainting for the exhibition. Navajo tradition ascribes a medicinal property to sand paintings, and requires the paintings destroyed upon completion without rendering the image. While the sand from Magiciens was scattered throughout the desert after the conclusion of the show, many photographs of the painting were captured during and after its creation (Martin, 1989). While this approach to Indigenous curation sought to incorporate ritualistic and 
cultural aspects of Indigenous life, it continued to perpetuate a colonialist within its curation.

\section{Where do We Go from Here?}

Recently, the concept of museum decolonization has been at the forefront of discussions surrounding institutions curating Indigenous works. More than just appealing to the aesthetic or historical connotations of artifacts, museum decolonization aims to address a larger issue: undoing years of cumulative emotional and psychological trauma that spans generations (Lonetree, 2012). Museums are often painful spaces for marginalized communities, history preserved by a colonial culture is inherently tied to the process of colonization, reiterating imperialism through presentation and historical recounting.

The act of decolonizing can have many facets: for those institutions which represent North American history, decolonization includes tribal self-determination, for institutions focused on art, it includes moving away from a platform of elitism and creating a space for community engagement. In all cases, it includes addressing the truths of colonialism and imperialism, and creating a space that may generate healing of unresolved, historical grief.

In 1994, New Zealand's national museum, Te Papa Tongarewa, addressed the division of historical representation in their institution and developed a strategic plan which would represent the history and culture of Tangata Whenua (the Indigenous, Māori people of New Zealand), and the Tangata Tiriti (people in New Zealand as a result of resettlement). To this day, Te Papa is one of the most exemplary accounts of institutional 
biculturalism, and much of the success of its decolonization efforts are a result of the unity of the National Museum and National Art Gallery, reiterating that particularly in cases of colonialism, both entities are inexplicably tied.

Puawai Cairnes, Senior Curator Mātauranga Māori at Te Papa, discussed efforts of museum decolonization in a national museum with me. One of the biggest challenges she was quick to identify was the lack of representation in every area. "Diversity used to mean two seats at a table of ten" were occupied by Indigenous individuals. Though Te Papa has overcome tokenism in many of the curatorial, managerial and administrative departments, there is still a need for more people on the ground (personal communication, October 28,2018$)$. That is, representation is only equal if there are Māori represented at every level within the institution.

When I ask if white curators have a role in decolonization, Cairnes pauses for a moment before she answers. "Yes," she acknowledges there is a need for Indigenous allies (or accomplices as she prefers to call them). "The best non-Indigenous curators take advantage of the system [of imperialism] on behalf on [Indigenous] communities. It's about acting in a way to open the space" (personal communication, October 28, 2018). She continues to stress the importance of curating for the people. The danger of nonIndigenous (and even some Indigenous) curators is that empathy can quickly spiral into an imagined imposition; many times, curators will project the empathy they want to experience, rather than creating an outcome the community actually wants. "And it's hard, you know? If you curate something the community doesn't want, you may get in trouble with your boss. If I do, I get in trouble with my mum. And that's always worse, when your people are mad at you." The experience of imagined empathy isn't a peril on 
the non-Native curator alone, but the risk of misrepresenting an entire community can be reduced by alleviating the responsibility of representation from a token individual.

I asked Melanie Yazzie, a Diné print artist in Colorado, the same question. "It's about collaboration with Indigenous communities," not just consultation. Non-Native curators have access to funds that Native artists do not: this includes funding, influence, and collaboration. "Compensation makes a huge difference. I see other, non-Native artists and what they're [earning]...I think in looking at how we get treated as artists is something that's overlooked. And there's lots of ways we can look at decolonizing, but I think looking at the pay structure and how people are valued in that way is gigantic" (personal communication, October 29, 2018). Developing artistic talent, improving the quality of Indigenous institutions, and collaboration are fundamental to museum decolonization; all of which is controlled by the financial resources available to Natives in the field. This is a resource that non-Native curators have a lot more access to she adds.

On October 4th, 2018, the Metropolitan Museum of Art unveiled the Art of Native America exhibition, featuring the expansive collection of Charles and Valerie Diker. The Met, which has an extensive collection of "primitive" arts, curated in a manner directly inspired by d'Harnoncourt, is presenting this exhibition in the American Wing. The collection was curated by two guest-curators of American Indian art: Gaylord Torrence and Marjorie Alexander from the Nelson-Atkins Museum of Art. Both curators are non-Native. The exhibition had an advisory committee that featured three Indigenous individuals (out of seven), and featured wall text from Indigenous leaders. The Dikers requested as a condition of their contribution that the collection was classified as 
"American art rather than tribal art," (Angeleti, 2018). The hope is that it will help recontextualize the definition of American art.

The couple, who has been establishing their private collection since the 1970s, acknowledge that their collection "was not about purchasing an artist, but rather preserving a culture and an aesthetic" (Angeleti, 2018). Nearly three quarters of a century after Culin's infamous collection, in the mind of collectors, the vanishing Indian is still a threat, and the salvage paradigm is still alive. 


\section{CONCLUSION}

This paper is by no means a comprehensive understanding of the Indigenous art and artifact market. This filed expands millennia, continents, political movements, and changes in culture and technology. Practicing ethical collection and curation requires collaboration and representation from all those who are affected; in the United States institutions such as the Smithsonian National Museum of the American Indian must represent more than 500 nations, and serve various stakeholders from each. The process of museum decolonization is also a process that is highly individualistic, responding to the unique culture which the museum represents, but moreover requires examining paradigms and perspectives which have formed current curatorial practices and establishing a new position that serves to change institutions for the better. 


\section{REFERENCES}

Angeleti, Gabriella (2018, October 2nd). Metropolitan Museum of Art reclassifies statues of native American art for new exhibition. The Art Newspaper. Retrieved from https://www.theartnewspaper.com/preview/met-reclassifies-status-of-nativeamerican-art

Ashevak, Kenojuak. (1993) Forward. In West Baffin Eskimo Cooperative. 1993 Cape Dorset Annual Graphics Collection (Annual Catlogue)

Barclay, Isabel, et al. Art of the Canadian Indians and Eskimos: L'art Des Indiens Et Des Esquimaux Du Canada. [Exhibition, National Gallery of Canada, Nov. 21, 1969Jan. 11, 1970. 1970.

Batkin, Jonathan, and Taylor Museum. (1987). Pottery of the Pueblos of New Mexico, 1700-1940. Taylor Museum of the Colorado Springs Fine Arts Center.

Berlo, Janet Catherine, and George and Joanne MacDonald. (1992). Collection of Northwest Coast Art. The Early Years of Native American Art History: The Politics of Scholarship and Collecting. University of Washington Press, 1992.

Berlo, Janet Catherine, and Ruth B Phillips. (1998). Native North American Art. Oxford University Press.

Billson, Janet Mancini, and Kyra Mancini. (2007). Inuit Women: Their Powerful Spirit in a Century of Change. Rowman \& Littlefield.

Bolz, Peter, et al. (1999). Native American Art: The Collections of the Ethnological Museum Berlin. University of Washington Press.

Brody, J. J. (1971). Indian Painters \& White Patrons. University of New Mexico Press.

Brooklyn Museum Archives, CAC, The Indians of The Southwest, A Course of Lectures Delivered in the Museum of Brooklyn Institute of Arts and Sciences, 1904 p. 5

Carlson, Paul Howard. (1998). The Plains Indians. 1st ed. ed., Texas A \& M University Press.

Carpenter, Edmund, et al. (2007). Eskimo. University of Toronto Press, 1959. Cobb, Daniel M, and Loretta Fowler. Beyond Red Power: American Indian Politics and Activism Since 1900. 1st ed. ed., School for Advanced ResearcH.

Clarke, Maxine. (2008, January 16). Hope for Artists. The Koori Mail, p. 26 
Colwell, C. (2017). Plundered skulls and stolen spirits: Inside the fight to reclaim native america's culture. Chicago: University of Chicago Press.

Cook-Lynn, E. (2001). Anti-Indianism in modern America: A voice from tatekeya's earth. Urbana, Ill.: University of Illinois Press.

Crandall, R. (2005). Inuit Art: A history. Jefferson, N.C.: McFarland.

Crowe, K. (1991). A history of the original peoples of northern canada (Rev. ed.). Montreal: McGill-Queen's University Press.

Darnell, Regna, et al. Historicizing Canadian Anthropology. U.B.C. Press, 2006.

Dawdy, Doris Ostrander. Annotated Bibliography of American Indian Painting. Museum of the American Indian, Heye Foundation, 1968.

d'Harnoncourt, Rene. (1939) Letter to Alfred H. Barr, Jr. November 8; IACB box 34.

Dockstader, Frederick J. Indian Art in America: The Arts and Crafts of the North American Indian. Promontory Press, 1974.

Doggett, Rachel, et al. New World of Wonders: European Images of the Americas, 14921700. Folger Shakespeare Library, 1992.

Driskill, Q., Finley, C.. Gilley, B. J., \& Morgensen, S. L. Queer Indigenous Studies: Critical Interventions in Theory, Politics, and Literature. University of Arizona Press, 2011.

Dunn, Dorothy. American Indian Painting of the Southwest and Plains Areas. First edition. ed., University of New Mexico Press, 1968.

Eber, Dorothy. (1993) Talking with the Artists. In Canadian Museum of Civilization $(1993 ; 425-42)$

Ewers JC. Early White Influence Upon Plains Indian Painting. Washington: Smithsonian Institution; 1957.

Feeney, John, and Daly, Tom. (1963) Eskimo Artist: Kenojuak. Canada: National Film Board of Canada.

Greene, Jerome A. American Carnage: Wounded Knee, 1890. University of Oklahoma Press, 2014.

Grounds, Richard A, et al. Native Voices: American Indian Identity and Resistance. University Press of Kansas, 2003.

Harkin, Michael Eugene, and David Rich Lewis. Native Americans and the Environment : Perspectives on the Ecological Indian. University of Nebraska Press, 2007.

Hessel, Ingo, and Dieter Hessel. Inuit Art: An Introduction. Harry N. Abrams, 1998. 
Hill, Greg A, et al. Sakahàn: Sakahàn: International Indigenous Art / International Indigenous Art. National Gallery of Canada, 2013.

Horner, Alice E. Reviewed Works: Objects of Myth and Memory: American Indian Art from the Brooklyn Museum by Brooklyn Museum, Diana Fane, Ira Jacknis, Lise M. Breen; The Journal of American Folklore, Vol. 105, No. 418 (Autumn, 1992), pp. $471-475$

Hou, Hanru. (2014). In Defence of Difference: Notes on Magiciens d la terre, Twenty-five Years Later. Yishu: journal of Contemporary Chinese Art 13, n0. 3. Pp. 7-18.

Houston, James (1954). Canadian Eskimo Art. Department of Northern Affairs and National Resources.

Houston, James. (1967). Eskimo Prints. Barre Pub.

Huntington, Ellsworth. (1919). The Red Man's Continent: A Chronicle of Aboriginal America. Yale University Press.

Johnson, Sandy (1994). The Book of Elders: The Life Stories of Great American Indians. 1st HarperCollins pbk. ed. ed., HarperSanFrancisco.

Josephy, A. (1994). 500 nations : An illustrated history of north american indians (First ed.). New York: Knopf.

Langness, L. L. The Study of Culture. 3rd rev. ed. ed., Chandler \& Sharp, 2005.

Light, Steven Andrew, and Kathryn R. L Rand. Indian Gaming \& Tribal Sovereignty: The Casino Compromise. University Press of Kansas, 2005.

Lonetree, A. (2012). Decolonizing Museums: Representing Native America in national and tribal museums(First peoples : new directions in indigenous studies). Chapel Hill: University of North Carolina Press. (2012).

Lowie, Robert Harry. Indians of the Plains. Bison Book Edition, 1985.

Lowie, Robert Harry. Primitive Society. Boni and Liveright, 1920.

Lowman, C. (2018). Marking ownership on ainu objects: Three museum collections in the united states. Museum Anthropology, 41(1), 46-60. doi:10.1111/muan.12168

Martin, J. (1989) Centre Georges Pompidou, Musée national d'art moderne (France), \& Musée national des sciences, des techniques et des industries (France). Magiciens de la terre : Centre georges pompidou, musée national d'art moderne, la villette, la grande halle. Paris: Editions du Centre Pompidou.

Maurer, Evan M, et al. Visions of the People: A Pictorial History of Plains Indian Life. Minneapolis Institute of Arts, 1992. 
McCleary, T. (2016). Crow indian rock art : Indigenous perspectives and interpretations. Walnut Creek, California: Left Coast Press.

McEvilley, T. (1992). Art \& Otherness: Crisis in cultural identity (1st ed., Mcpherson \& co). Kingston, NY: Documentext/McPherson.

Meyer, C., \& Royer, D. (2001). Selling the Indian: Commercializing \& appropriating american indian cultures. Tucson: University of Arizona Press.

Newcomb, Steven (2004, December 8). On the Words 'Tribe' and 'Nation.' Indian Country Today. Retrieved from: https://newsmaven.io/indiancountrytoday/archive/on-the-words-tribe-and-nationNUTfP-tyU0uqza8cle2BSg/

Nittle, Nadra Kareem. (2018, September 20). Interesting Facts and Information About the Native American Population. Retrieved from: https://www.thoughtco.com/interesting-facts-about-native-americans-2834518

Official Report of the Nineteenth Annual Conference of Charities and Correction (1892), 46-59. Reprinted in Richard H. Pratt, "The Advantages of Mingling Indians with Whites," Americanizing the American Indians: Writings by the "Friends of the Indian" 1880-1900 (Cambridge, Mass.: Harvard University Press, 1973), 260271.

Ostrowitz, Judith (2009). Interventions: Native American Art for Far-Flung Territories. University of Washington Press, 2009.

Owensboro Museum of Fine Art (Ky.). The Art of the Native American: The Southwest from the Late 19th Century to the Present. Owensboro Museum of Fine Art, 1985.

Ray, Dorothy Jean, and Henry Art Gallery. Eskimo Art: Tradition and Innovation in North Alaska. Published for the Henry Art Gallery by the University of Washington Press, 1977.

Roch, Ernst, et al. Arts of the Eskimo: Prints. Barre, 1975.

Rushing, W. Jackson. Native American Art and the New York Avant-Garde: A History of Cultural Primitivism. 1st ed., University of Texas Press, 1995.

Said, E. (1994). Orientalism (25th anniversary edition. with a new preface by the author ed.). New York: Vintage Books.

Thomas, Nicholas. Possessions: Indigenous Art, Colonial Culture. Thames \& Hudson, 1999.

Wade, Edwin L, et al. Magic Images: Contemporary Native American Art. Philbrook Art Center, 1981.

Wheeler-Howard Act, 25 U.S.C. ch. 14, subch. V § 461 et seq. (1934) 
White, H. (1978). Tropics of Discourse: Essays in cultural criticism. Baltimore: Johns Hopkins University Press. 


\section{CURRICULUM VITA}

NAME:

ADDRESS:

DOB:

EDUCATION

\& TRAINING:

AWARDS:

PROFESSIONAL SOCIETIES:
Adelaide McComb

Hite Department of Fine Arts

104 Schneider Hall

University of Louisville

Louisville, KY 40292

Denver, Colorado - December 1, 1988

B.A. Communication Studies

Colorado State University

2008-2011

Visual Resource Association Foundation Internship Award 2018

Visual Resource Association 